\title{
Curriculum 4.0: Adoption of Industry Era 4.0 as Assessment of Higher Education Quality
}

\author{
Chandra Lukita ${ }^{1}$,Suwandi ${ }^{2}$, Eka Purnama Harahap* ${ }^{3}$, Untung Rahardja ${ }^{4}$, Chairun $\mathrm{Nas}^{5}$ \\ ${ }^{1,2,5}$ System Information, University of Catur Insan Cendekia, Indonesia \\ ${ }^{3,4}$ Master Program Information Technology, University of Raharja, Indonesia \\ e-mail: ${ }^{1}$ chandralukita@ cic.ac.id, ${ }^{2}$ suwandi@ cic.ac.id, *³ ekapurnamaharahap@ raharaja.info, \\ untung@raharja.info, ${ }^{5}$ chairun.nas@cic.ac.id
}

\begin{abstract}
Abstrak
Indonesia merupakan negara terbesar ke-4 di Asia Tenggara dengan populasi 262 juta yang perlu dipertimbangkan tingkat kesuksesan Sumber Daya Manusianya, sebab Negara yang kuat adalah Negara yang memiliki pondasi kokoh, salah satu contohnya adalah kecerdasan SDM. Persaingan global membuktikan bahwa SDM membutuhkan kompetensi yang kuat disegala bidang, umumnya di bidang teknologi. Namun, kurangnya pendidikan yang merata, serta sistem pendidikan yang masih konvensional, membuat negara Indonesia jauh tertinggal dibandingkan dengan negara tetangga lainnya. Tantangan era 4.0 ini menjadi peluang untuk memunculkan pengembangan kombinasi antara Industri 4.0 dengan kurikulum pendidikan di Indonesia. Ada empat isu yang diangkat mengapa sistem kurikulum pendidikan Indonesia perlu ditinjau kembali. Adanya studi literatur dan metode analisis SWOT digunakan sebagai referensi dalam menyelesaikan masalah dalam ruang lingkup yang signifikan. Pada tulisan ini, kompetensi diperlukan untuk memungkinkan keberhasilan antara integrasi manajemen pendidikan dengan era industri 4.0 yang akan dibahas lalu dianalisis berdasarkan fakta dan realitas sistem pendidikan di Indonesia yang kemudian dapat disajikan dalam kurikulum yang komprehensif.
\end{abstract}

Kata kunci-Era Industri 4.0, Manajemen Pendidikan, Kurikulum 4.0

\begin{abstract}
Indonesia is the 4th largest country in Southeast Asia with a population of 262 million which needs to be considered the success rate of its human resources, because of a strong country that has a strong foundation, one example is the intelligence of human resources. Global competition proves that HR requires strong competence in all fields, generally in the field of technology. However, the lack of equitable education, as well as the conventional education system, makes the country of Indonesia far behind compared to other neighboring countries. The challenge of this 4.0 era is an opportunity to bring up the development of a combination of Industry 4.0 and the education curriculum in Indonesia. There are four issues why the Indonesian education system and curriculum needs to be reviewed. Where there is a literature study and SWOT analysis method used as a reference in solving problems and there is a significant scope. In this paper, competencies are needed to enable success between the integration of education management and the industrial era 4.0 which will be discussed and analyzed based on the facts and reality of the education system in Indonesia which can then be presented in a comprehensive curriculum.
\end{abstract}

Keywords- Industrial Era 4.0, Education Management, Curriculum 4.0

Received June $26^{\text {th }}, 2020$; Revised July $28^{\text {th }}, 2020$; Accepted July $30^{\text {th }}, 2020$ 


\section{INTRODUCTION}

Indonesia is building its human resources, including highly educated human resources. Indonesia's education system is developing quite rapidly quantitatively, but in terms of quality it needs to grow faster and higher to catch up and parallel with higher education in developed countries.

According to the Law of the Republic of Indonesia Number 20 of 2003 concerning the National Education System where education is a conscious and planned effort to create an atmosphere of learning and learning process so that students actively develop their potential to have religious spiritual strength, self-control, personality, intelligence, morals noble, as well as the skills needed by himself, society, nation and state [1]. The goal of the national education system which has a mission in developing "self potential" certainly makes Universities deserve to reflect on the systems implemented in realizing compatible human resources in the industrial era 4.0. Intense competition between higher education in Indonesia, makes Universities compete to score a generation of graduates who are rich in hi-tech knowledge or what is often referred to as the industrial era 4.0.

The industrial era 4.0 aims to modernize all forms of activity in the community, especially in the field of education [2]. Where, paper, ballpoint pens, and various conventional learning tools began to be left behind slowly. This is a characteristic that the industrial era 4.0 has begun. According to Mayling Oey-Gardiner, et al as quoted in his e-book, the era of disruption is actually the fruit of research activities and the results of technological innovation can be a new starting point for universities in Indonesia. Where, universities become intermediaries between human resources with the competencies possessed by each of these human resources [3].

\section{Arrangement of KKNI Development}

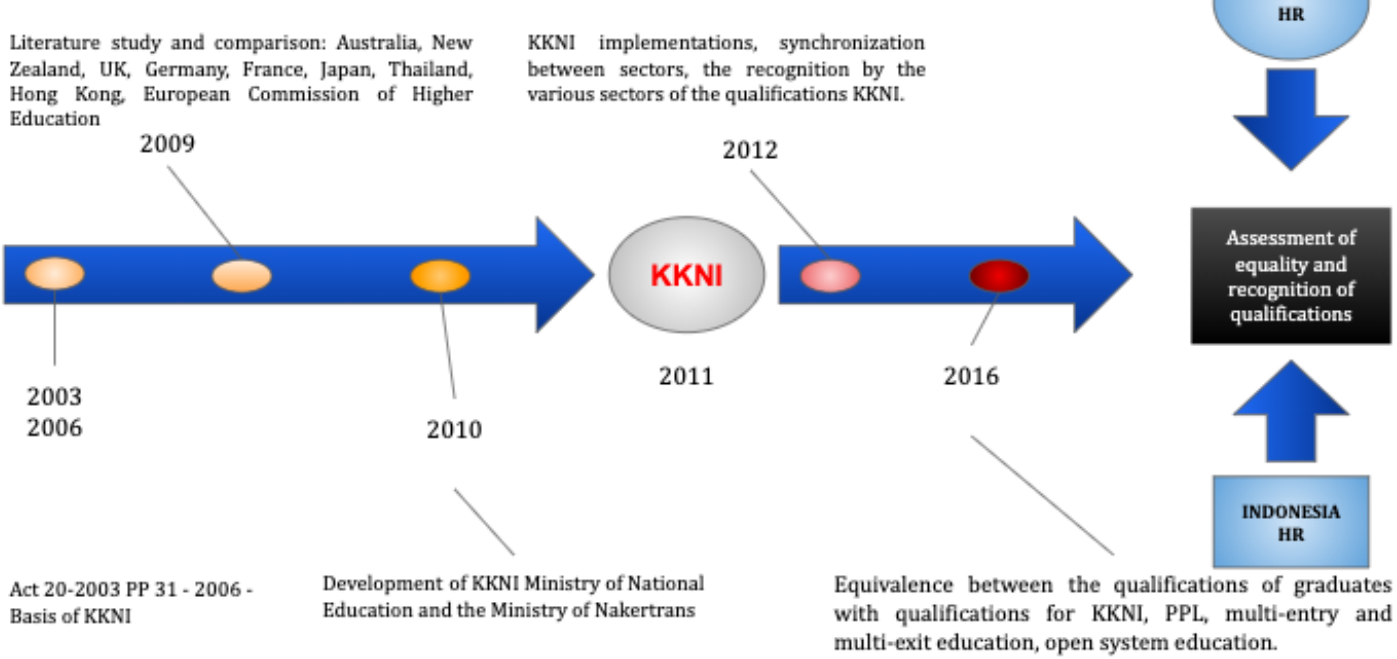

Figure 1 Arrangement of KKNI Development

Based on Figure 1 describes the development of the IQF which is in line with the 4.0 era in higher education in Indonesia. Where, the Indonesian National Qualification Framework (KKNI) is a framework for qualification of Indonesian human resource qualifications that juxtaposes, equalizes, and integrates the education sector with the training sector and work experience in a work skills recognition scheme that is adapted to the structure in various employment sectors.

Higher Education, which is the most reliable foundation for human resources in a

IJCCS Vol. 14, No. 3, July 2020 : 297 - 308 
country, is expected to contribute to producing graduates who have qualifications in line with the industrial era 4.0 currently being fostered. Tight competition between foreign human resources and Indonesian human resources in conquering the industrial era 4.0 is a benchmark for the success of Higher Education in creating quality graduates.

According to Budi Djatmiko there are three ways to anticipate the emergence of disruptive innovation. First, Universities must always monitor the emergence of new technologies. Second, monitoring the direction of technological developments that are currently being undertaken [4]. And third, create separate business units to be able to optimize new technologies that have been recognized. In addition, referring to the Law of the Republic of Indonesia Number 20 of 2003 that the curriculum is a set of plans and arrangements regarding the objectives, content, and learning materials as well as the ways used as guidelines for organizing learning activities to achieve certain educational goals. Thus, it is hoped that a curriculum modification towards 4.0 can be a breakthrough and new innovation in creating human resources capable of competing in the industrial era of 4.0 and having the qualifications to compete with foreign human resources that have now penetrated the Indonesian arena.

\section{Curriculum 4.0: Integration of Curriculum and Industry 4.0}

Specific skills in Industry 4.0 technology found in the education system need to be given to their graduates taking into account several modern educational trends [5]. This tends to include: opportunities to study at various times and places (distance education); personal learning based on student abilities; use of new learning tools, tools and resources; remote engineering laboratory; application of project-based and problem-based learning approaches; the use of collaborative experiential learning; and the involvement of higher education in designing industry-based curriculum 4.0 [6].

The higher education curriculum listed in the Law of the Republic of Indonesia Number 20 of 2003 only requires 3 (three) focuses which include religious education; civic education; and language. Of course this can make the competence of students to compete in the global market far from possible. Where, the required curriculum is only based on conventional theory. So, with the 4.0 industrial revolution, universities need to integrate the curriculum with the 4.0 industrial revolution era thus, the development of Indonesian HR competencies that are still conventional based can gradually turn into competencies that can be competed with foreign human resources.

In order to prepare a reliable and professional workforce in the field of each human resource, it is necessary to have a standard device that can measure and screen workers who meet the requirements according to their competence [7]. The standards that will serve as benchmarks here refer to the Indonesian National Work Competency Standards (SKKNI) in 2007. Where there are 4 (four) main components in the SKKNI that need to be developed, namely: a. Ability in the task (task skill), b. The ability to manage tasks (task management skills), c. The ability to deal with a problem appropriately (contingency management skills), d. Ability to adjust to the work environment (job environment skill). Of the four SKKNI requirements, a higher education curriculum should also be adjusted. As written, the curriculum of higher education can be developed by the relevant tertiary institution with reference to national education standards for each study program. By following the basic framework and structure of the higher education curriculum [8].

Indonesian HR readiness in facing the challenges of the industrial revolution 4.0 is formed through the development of skills using digital technology [9]. Today, digital technology that is known and rife in society is no longer a strange thing that should be learned with a course. Various data, information, news and so on have been easily obtained by selftaught. Likewise with the world of education, human resources, especially academics, are now easier to find educational solutions through technology than conventional (libraries and so on). Of course this is the main basis for the need for strong integration between the curriculum and the 4.0 revolution.

Curriculum 4.0: Adoption of Industry Era 4.0 as Assessment of Higher ... (Chandra Lukita) 


\section{Curriculum 4.0: Countries that consider curriculum changes}

The rise of technology-based education and CS (computer science) is not only developing in Indonesia. Recently, the industrial revolution 4.0 is indeed very popular among the people of Indonesia which is often referred to as the era of disruption, where the conventional will be far behind. However, besides that, in fact, several countries in Europe are considering the balance between the curriculum with the development of technology and CS [10].

Based on reports from members of the International Federation of Information Processing (IFIP), it is suggested that the UK and Australia are indeed not alone in considering changes with CS balance in the curriculum. Although there are various arguments in this determination, since May and June 2015, thirteen national reports on education and technology have separately identified how countries spread across four continents are considering CS in the compulsory education curriculum [11].

With the presence of countries that are also considering curriculum changes. So, higher education in Indonesia needs a strategy to balance the curriculum with developments in this era of disruption. By using the method that will be explained in detail in the next sub-chapter.

This paper contributes in providing literature and managerial advice in developing curriculum based on integration and in line with industry 4.0.

\section{METHODS}

In developing a 4.0-based curriculum, there is a need for each university's policies to be in line with each determined study program. Government policy has also become one of the factors supporting the successful implementation of the 4.0-based curriculum, especially in Higher Education in Indonesia. In this study, there are two methods adopted to solve the challenges that will be faced in the era of disruption 4.0, including;

\section{Literature Study Methods}

Literature Study Method or literature review is a series of theories, findings and previous research or have been used as a basis for further research activities in preparing the framework of the problem being studied [12]. Where in this study, there have been at least 5 (five) literature studies related to research being examined at this time.

Judith Enke et al argued that curriculum adjustments emerged from new challenges facing companies in a changing industrial environment. This background is also taken from learning factories which are used as a place for education and training that must rethink the content in the learning modules. Especially, the competency that has recently emerged is the Industry 4.0 approach. Based on this, the competencies in question can be derived and formulated in detail as shown in the example of the new learning module "Fundamentals of Lean 4.0" [13]. In addition, Mo Elbestawia presents a learning factory at W Booth School of Engineering Practice and Technology at McMaster University, Canada. The focus of the learning factory here is to provide students, industrial employees and laboratory researchers to enable users to understand, learn and apply modern manufacturing approaches such as Industry 4.0, IoT, IIoT, and additive manufacturing. In this implementation the approach has been provided a communication infrastructure environment that is flexible, flexible assembly, adequate, and quality. The aim of the SEPT learning factory is to simulate an integrated production environment through many elements, including the Industry 4.0 paradigm. Students and industrial employees are expected to understand these principles [14]. On the other hand Don Passey stated that there were at least six arguments outlined above that were the reasons for curriculum changes. Although research needs to start by strategically exploring the new curriculum, the starting point of the evidence needs to be well understood and established.

IJCCS Vol. 14, No. 3, July 2020 : 297 - 308 
This point is echoed in the EDUsmmIT research report (2015), which identifies a number of key research questions and problems. The learning argument implies that students acquire skills and value competencies for them, for the future and in the present (problem-solving skills and creativity, and programming skills) [15]. Increasing demand for the introduction of career education in high school to increase the transition of students from learning to the world of work. Against such a background, this paper aims to discuss curriculum reforms and support structures in schools and to explore the challenges of life skills planning for high school students in China with specific references from Hong Kong. This paper will also predict its implications in the future development of CLPE, (John Chi-Kin Lee, 2016) [16]. Mega Apriyani et al., Found that the results of the study showed that first, curriculum planning in SMP PGRI 1 Pulaupanggung was based on the results of previous evaluations and the preparation of targets and programs compiled. Second, organizing the curriculum includes dividing teaching assignments for teachers in accordance with their respective fields of expertise, striving for teachers to teach five days in one week, compile a schedule of repairs / remedial activities, hold tutoring and try out, arrange a schedule of activities extracurricular, arrange teaching schedules for teachers about science and technology. Third, the curriculum's implementation includes initial learning activities, learning methods, learning media, and final learning activities. Fourth, curriculum evaluation uses a form of assessment of cognitive aspects, affective aspects, and psychomotor aspects [17]. So, from the five studies able to be supported in research, almost most of them have the same variable about the education curriculum. Besides that, the discussion of each study uses a variety of methods in solving a problem. One approach that is almost in line is the development of technological science to achieve competent graduates. A comparison between previous research and the research being studied at this time is the existence of a new educational curriculum strategy in implementing Student-Centered Learning (SCL) with the iLearning (Integrated Learning) approach [18].

\section{SWOT Analysis Method}

Rangkuti said that the SWOT analysis is a form of situation and condition analysis that is or provides an illustration. This analysis places the situation and conditions as input factors, grouped according to their respective contributions [19].

\section{SWOT ANALYSIS}

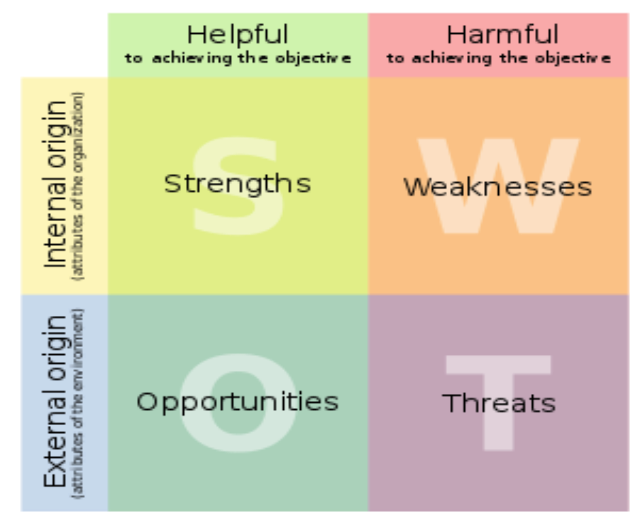

Figure 2 SWOT Analysis

a. Strength (S), is a situation or condition that is the strength of the organization.

b. Weakness (W), is a situation or condition that is a weakness of the organization.

c. Opportunity (O), is a situation or condition that is an opportunity outside the organization and provides opportunities for the organization in the future.

d. Threat (T), is a situation that is a threat to organizations that come and threaten their existence in the future. 
Based on Table 1 this study also explained using the SWOT analysis method to evaluate Strengths, Weakness, Opportunities, and Threats in developing 4.0-based curriculum in Higher Education.

Table 1 SWOT Analysis

\begin{tabular}{|c|c|c|}
\hline Internal Factor & Strength & Weakness \\
\hline External Factor & $\begin{array}{l}\text { Indonesia is a country that } \\
\text { has several tertiary } \\
\text { institutions reaching >= } \\
5,000 \text { tertiary institutions, } \\
\text { both public and private. } \\
\text { According to Law Number } \\
20, \text { the Year 2003, Higher } \\
\text { Education is held in an } \\
\text { open system. That is, each } \\
\text { individual has the right to } \\
\text { receive a higher education } \\
\text { to achieve better survival. }\end{array}$ & $\begin{array}{l}\text { According to a Political and } \\
\text { Economic Risk Consultant } \\
\text { (PERC) survey, the quality of } \\
\text { education in Indonesia ranks } \\
12 \text { th out of } 12 \text { countries in } \\
\text { Asia. Indonesia's position is } \\
\text { under Vietnam. Data reported } \\
\text { by The World Economic } \\
\text { Forum Sweden (2000) shows } \\
\text { that Indonesia has low } \\
\text { competitiveness, which only } \\
\text { ranks } 37 \text { th out of } 57 \text { countries } \\
\text { surveyed in the world. }\end{array}$ \\
\hline Opportunities & SO & WO \\
\hline $\begin{array}{l}\text { Education curriculum to achieve } \\
\text { quality education needs to be } \\
\text { developed in line with } \\
\text { technological developments and } \\
\text { CS, which is now referred to as } \\
\text { the industrial revolution } 4.0 \text {. } \\
\text { Besides, the rise of scholarships } \\
\text { for students who have } \\
\text { competence in the global market } \\
\text { needs to be improved. }\end{array}$ & $\begin{array}{l}\text { There is a need for action } \\
\text { from }>=5,000 \text { tertiary } \\
\text { institutions that can } \\
\text { compensate and renew the } \\
\text { Higher Education } \\
\text { curriculum for the } \\
\text { achievement of human } \\
\text { resources that can compete } \\
\text { in the current } 4.0 \text { industry } \\
\text { era. The curriculum, which } \\
\text { will later be referred to as } \\
\text { curriculum } 4.0 \text {, is a } \\
\text { curriculum where HR } \\
\text { competencies are in line } \\
\text { with technological } \\
\text { developments and CS. }\end{array}$ & $\begin{array}{l}\text { The challenge of the } \\
\text { industrial revolution } 4.0 \text { can } \\
\text { be an excellent opportunity } \\
\text { for Indonesia's quality of } \\
\text { education, which is far } \\
\text { behind. Where the renewal of } \\
\text { competencies by overhauling } \\
\text { the curriculum based on the } \\
\text { industrial revolution, } 4.0 \text { can } \\
\text { be a way of human resource } \\
\text { development in Indonesia. }\end{array}$ \\
\hline Threats & ST & WT \\
\hline $\begin{array}{l}\text { Free competition for foreign } \\
\text { higher education to operate in } \\
\text { the territory of the Republic of } \\
\text { Indonesia. }\end{array}$ & $\begin{array}{l}\text { The presence of foreign } \\
\text { universities that have } \\
\text { recently entered the } \\
\text { Republic of Indonesia's } \\
\text { territory should not make } \\
\text { several>= } 5,000 \text { Indonesian } \\
\text { universities. With the large } \\
\text { number of individuals who } \\
\text { can study tertiary education } \\
\text { in Indonesia and easy } \\
\text { access to such knowledge, } \\
\text { it certainly can reduce the } \\
\text { concerns of higher } \\
\text { education practitioners. }\end{array}$ & $\begin{array}{l}\text { Free competition between } \\
\text { Indonesian universities and } \\
\text { foreign universities should be } \\
\text { able to motivate universities } \\
\text { in Indonesia to continue to } \\
\text { improve the quality of } \\
\text { education so that the presence } \\
\text { of international universities } \\
\text { cannot be a competitor so } \\
\text { feared.. }\end{array}$ \\
\hline
\end{tabular}

IJCCS Vol. 14, No. 3, July 2020 : 297 - 308 


\section{RESULTS AND DISCUSSION}

Looking at the times from time to time, there is a need for a flashback before the coming of today. The world of education and even the wider community has never thought that current technological developments are reaching very quickly. They are evidenced by the application of facilities and infrastructure that support HR in getting data and information. With the amount of data and information obtained quickly, the HR thinking power also needs to be developed to become a user and become a creator. However, how strong HR can develop certainly becomes an essential role of Higher Education in favoring it.

Understanding the learning that is happening right now is considered to be less useful because it cannot create human resources that can compete in the world of work today as we know that in the industrial era 4.0, knowledge of technology is the primary key to competing in the global market. Not just being a user, but how human resources can create new things that can be featured on the national or international level.

Kadarsyah Suryadi assumed that the prediction in 2030 that 50 percent of employees would be dominated by computers [20]. And then the more there development and change will be faster. Therefore, actually, the curriculum that we have to do is fundamental.

There are at least four problems that are factors why there is a need for integration between curriculum and industry 4.0 which will later be referred to as curriculum 4.0, namely;

1. The development of websites and online sales will be more intense in the next few years. Even today, the online market is dominated by e-commerce websites. This is a challenge, how HR can master coding and programming.

2. With a lot of data and information that can be obtained online, then there is what is often referred to as big data, if HR cannot overcome it, it will undoubtedly be overwhelmed. There needs to be competition in the field of analytic data.

3. As explained earlier, currently, applications have helped many people, for example, only road maps or also called plans. For specific study programs and at a certain level, there needs to be skilled in the field of artificial intelligence; namely, the software can think to help HR.

4. And to print a generation that is ready in the following epochs, it is necessary to have human resources who can develop soft skill flexibility and sustainability systems. This is in line with the development of industry 4.0, which will continue to grow until 2030 or even more.

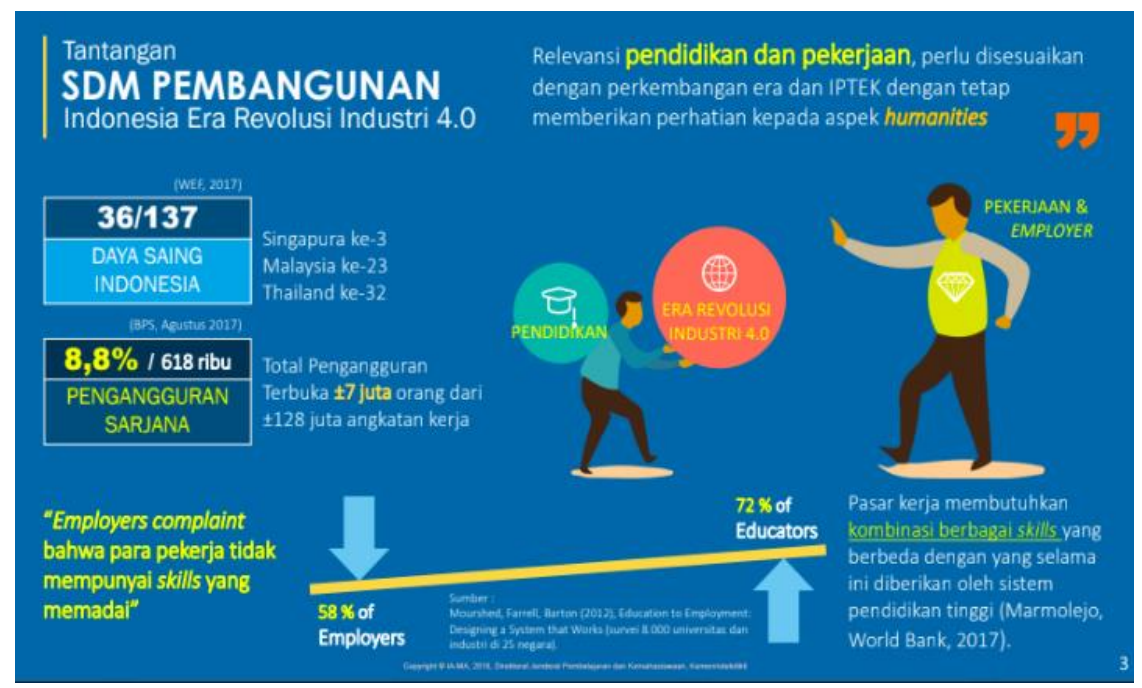

Figure 2 Development HR Challenges 
Marmolejo said that the job market requires a combination of various skills that are different from those that have been provided by the higher education system [21]. As explained in figure 2, the combination of the four problems can be beneficial if HR can apply it after graduation because the suitability or relevance between education and work needs to be balanced with technological advances that are currently developing. Thus, reducing the number of unemployed graduates who do not have adequate skills.

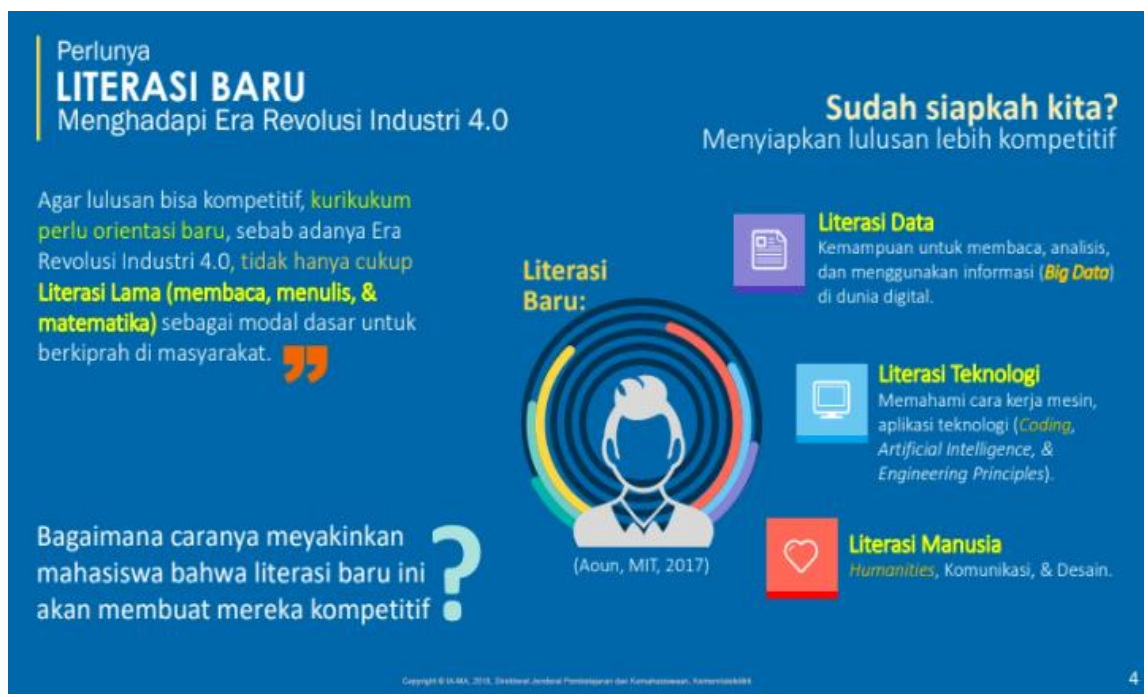

Figure 3 The Need for New Literacy in the Industrial Era 4.0

As has been suggested in figure 3 , for graduates to be competitive, there needs to be a new orientation in the higher education curriculum. The curriculum is a set of plans and arrangements regarding the objectives, content, and learning materials, as well as the methods used to guide the implementation of learning activities to achieve specific educational goals. Thus, Curriculum 4.0 is an amalgamation of the curriculum with Industrial Revolution 4.0 which will be a set of plans, regulations regarding the objectives, content, learning materials and guidelines for the implementation of technology-based learning activities where the focus is on promoting the relevance of education and the work of HR so that they can achieve a better education. Excels in the global market.

There are three things in preparing graduates who are more competitive in this 4.0 industry era, including data literacy, technology literacy, and human literacy. These three things are closely related to four problems that have been explaining before. Among them, HR with the ability to understand information (big data) in the industrial era 4.0, HR who need to understand and understand the performance of technology called (artificial intelligence), and finally the ability of soft skills and sustainability systems to make HR more ready to compete in the global market [22].

\section{Curriculum 4.0 based on iLearning}

Long before technology developed rapidly, based on Law Number 12 of 2012 concerning Higher Education, which contains in Article 31, which discusses distance education, as is known, distance education is a teaching and learning process that is done remotely through the use of various communication media [23].

So with these four problems, there needs to be a reform in the tertiary education curriculum. Not only focusing on one study program, but this industry-based 4.0 curriculum also needs to be implemented in specific fields that are still in the same knowledge group, not just focusing on the informatics technology study program. 


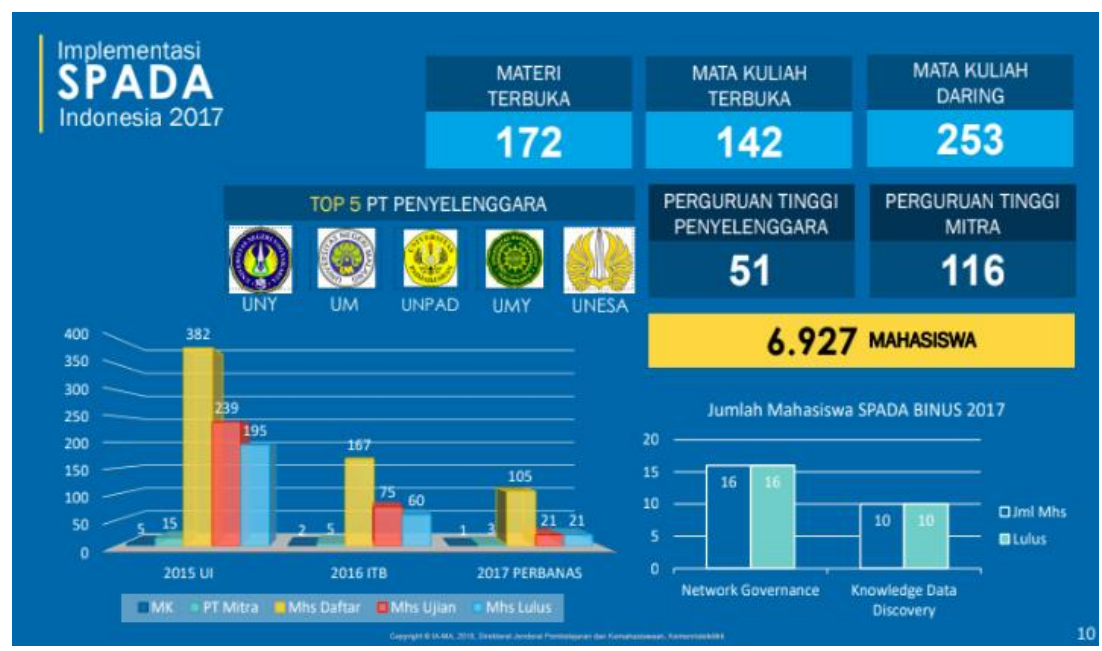

Figure 4 Implementation of SPADA Indonesia 2017

Based on figure 4, SPADA is an Indonesian Online Learning System organized by the Directorate General of Belmawa, facilitated by secure connections through the IdREN (backbone). SPADA Indonesia is one of the Directorate General of Learning and Student Affairs programs of the Ministry of Research, Technology, and Higher Education to improve equitable access to quality learning in Higher Education. With its online learning system, SPADA Indonesia provides opportunities for students from one tertiary institution to be able to take a specific quality course from another tertiary institution. The learning outcomes can be recognized equally by the tertiary institution where the student is enrolled [24].

Like SPADA Indonesia organizers, several universities certainly have their learning systems adapted to the development of the industrial era 4.0, one of which is the iLearning or Integrated Learning method. iLearning (Integrated Learning) derives from the thought of the development of iPad Technology at Raharja College, Learning, Playing, Praying, and Working. The growth in an efficient, practical, and enjoyable manner to make students more attractive and enthusiastic in learning with the support of technology facilitates the reach of students in conducting interactions [25].

The iLearning learning method is a concept of learning media coined in 2009 by Dr. Ir. Untung Rahardja, M.T.I., MM, by using iPad media (iLearning with iPad). And according to him, iLearning is 4B (Learning, Playing, Praying, Working). The iLearning learning method has ten learning support features summarized in TPi (Ten pillars of IT learning) [26].

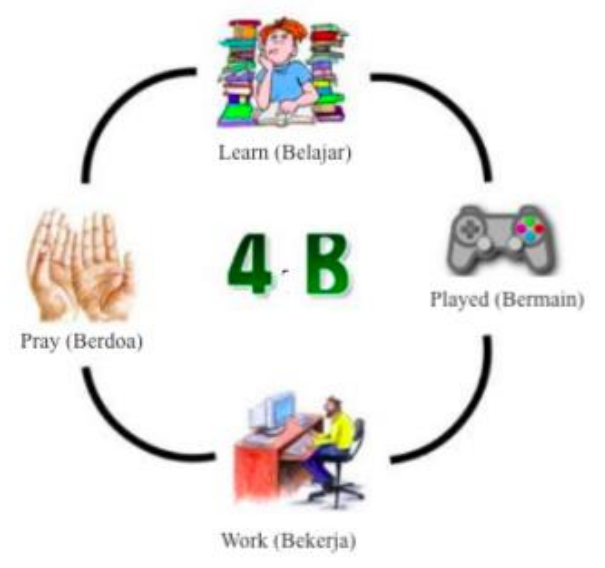

Figure 5 iLearning Method 
With the various online-based distance education concepts that have been applied by institutions of higher education, certainly can be a curriculum reference 4.0 to adopt a variety of learning methods that will facilitate HR in providing an understanding of technology and can be literacy for HR in competing in the world of work.

As seen in Figure 5 that Basically Integrated Learning develops from the thought of iPad Technology at a university. Learning, Playing, Praying, and Working efficiently, practically, and fun to make students more attractive and enthusiastic in learning with the support of technology that makes it easier for students to interact. Thus, understanding these four essential elements will be constructive in understanding iLearning.

\section{CONCLUSIONS}

The progress of the industrial era 4.0, especially in the world of education is a challenge that must be faced by universities in improving the quality of education management. Where Indonesia needs to improve the quality of workforce skills with digital technology. Higher Education for 4 (four) years considers useless when graduates do not have soft skills competing in the global market. That way, there needs to be a curriculum assessment towards curriculum 4.0 that implements 4 (four) competencies including programming, data analysis, ability in artificial intelligence, and soft skills flexibility and sustainability systems to produce superior and quality graduates and guarantee the quality of higher education in the industrial era 4.0 this. Besides building four competencies, higher education needs to adapt learning methods that have been applied by various campuses to create harmony in the quality of education.

Curriculum 4.0 is an amalgamation of the curriculum with Industry 4.0 4.0 which will be a set of plans, regulations regarding the objectives, content, learning materials and guidelines for the implementation of technology-based learning activities where the focus is on promoting the relevance of education and the work of HR so that they can achieve superior education in the global market.

It is hoped that by reforming the curriculum into curriculum 4.0, it will not only produce competent human resources in their fields. But it can guarantee the quality of higher education in line with the industrial era 4.0 in Indonesia.

\section{ACKNOWLEDGEMENTS}

This research supports the Minister of Research Technology and Higher Education in implementing the Tridharma of Higher Education. And thanks to Raharja University for their unlimited support. The author also wishes to thank the Alphabet Incubator for providing his place and guidance.

\section{REFERENCES}

[1] P. R. Indonesia, "Undang-undang Republik Indonesia nomor 20 tahun 2003 tentang sistem pendidikan nasional," Jakarta Pemerintah Republik Indones., 2003.

[2] Q. Aini, S. Riza Bob, N. P. L. Santoso, A. Faturahman, and U. Rahardja, "Digitalization of Smart Student Assessment Quality in Era 4.0," Int. J. Adv. Trends Comput. Sci. Eng., vol. 9, no. 1.2, pp. 257-265, Apr. 2020, doi: 10.30534/ijatcse/2020/3891.22020.

[3] M. Oey-Gardiner, "Gender differences in schooling in Indonesia," Bull. Indones. Econ. Stud., vol. 27, no. 1, pp. 57-79, 1991.

[4] L. T. Curtis, "Innovations in Learning," J. Sch. Health, vol. 38, no. 5, pp. 290-294, 
1968, doi: 10.1111/j.1746-1561.1968.tb05006.x.

[5] U. Rahardja, E. P. Harahap, and D. D. Christianto, "PENGARUH TEKNOLOGI BLOCKCHAIN TERHADAP TINGKAT KEASLIAN IJAZAH," Technomedia J., vol. 4, no. 2, pp. 211-222, 2020.

[6] Q. Aini, N. Lutfiani, F. Hanafi, and U. Rahardja, "Application of Blockchain Technology for iLearning Student Assessment," IJCCS (Indonesian J. Comput. Cybern. Syst., vol. 14, no. 2, 2020, doi: 10.22146/ijccs.53109.

[7] Q. Aini, U. Rahardja, and A. Khoirunisa, "Blockchain Technology into Gamification on Education," IJCCS (Indonesian J. Comput. Cybern. Syst., vol. 14, no. 2, pp. 1-10, 2020, doi: 10.22146/ijccs.53221.

[8] B. S. N. Pendidikan, "Peraturan Menteri Pendidikan Nasional Republik Indonesia Nomor 16 Tahun 2007," Jakarta BSNP, 2007.

[9] H. Suwardana, "Revolusi Industri 4. 0 Berbasis Revolusi Mental," JATI UNIK J. Ilm. Tek. Dan Manaj. Ind., vol. 1, no. 2, pp. 109-118, 2018.

[10] M. A. S. PRIHANTANA, I. W. Santyasa, and I. W. S. Warpala, "Pengembangan Bahan Ajar Interaktif Berbasis Pendidikan Karakter Pada Mata Pelajaran Animasi Stop Motion untuk Siswa SMK," J. Teknol. Pembelajaran Indones., vol. 4, no. 1, 2014.

[11] D. Passey, "Computer science (CS) in the compulsory education curriculum: Implications for future research,” Educ. Inf. Technol., vol. 22, no. 2, pp. 421-443, 2017.

[12] U. Rahardja, E. P. Harahap, and S. Pratiwi, "Pemanfaatan Mailchimp Sebagai Trend Penyebaran Informasi Pembayaran Bagi Mahasiswa Di Perguruan Tinggi," Technomedia J., vol. 2, no. 2, pp. 41-54, 2018.

[13] J. Enke, K. Kraft, and J. Metternich, "Competency-oriented design of learning modules," Procedia CIRP, vol. 32, no. 2015, pp. 7-12, 2015.

[14] M. Elbestawi, D. Centea, I. Singh, and T. Wanyama, "SEPT learning factory for industry 4.0 education and applied research," Procedia Manuf., vol. 23, pp. 249-254, 2018.

[15] D. Passey, "Technology enhancing learning: Analysing uses of information and communication technologies by primary and secondary school pupils with learning frameworks," Curric. J., vol. 17, no. 2, pp. 139-166, 2006.

[16] P. Blatchford, K. W. Chan, M. Galton, K. C. Lai, and J. C.-K. Lee, Class size: Eastern and western perspectives. Routledge, 2016.

[17] T. R. Sista, "Implementasi Manajemen Kurikulum Dalam Meningkatkan Mutu Pendidikan,” Educ. J. Pendidik. Islam, vol. 1, no. 1, 2017.

[18] F. Agustin, F. P. Oganda, N. Lutfiani, and E. P. Harahap, "Manajemen Pembelajaran Daring Menggunakan Education Smart Courses," Technomedia J., vol. 5, no. 1, pp. 4053, 2020.

[19] F. Rangkuti, Analisis SWOT teknik membedah kasus bisnis. Gramedia Pustaka Utama, 1998.

[20] K. Amila and K. Suryadi, "Keefektifan online knowledge sharing behavior (Studi Kasus: Blended learning ITB)," J. Rekayasa Sist. Ind., vol. 1, no. 01, pp. 129-136, 2016.

[21] I. Ahmad, "Proses pembelajaran digital dalam era revolusi industri 4.0," Direktur Jenderal Pembelajaran dan Kemahasiswaan. Kemenristek Dikti, 2018.

[22] P. R. Indonesia, "Undang-Undang Nomor 12 Tahun 2012 tentang Pendidikan Tinggi," Jakarta Sekr. Negara, 2012.

[23] U. Rahardja, N. Lutfiani, and H. L. Juniar, "Scientific Publication Management Transformation In Disruption Era," Aptisi Trans. Manag., vol. 3, no. 2, pp. 109-118, 
2019.

[24] P. Jozua Ferjanus and R. Nira, "TIM SPADA pada Seminar dan Workshop 'Optimasi Kuliah dengan Kerangka Sistem Pembelajaran Daring Indonesia (SPADA),” 2018.

[25] U. Rahardja, N. Lutfiani, E. P. Harahap, and L. Wijayanti, "iLearning: Metode Pembelajaran Inovatif di Era Education 4.0," Technomedia J., vol. 4, no. 2, pp. 261-276, 2020.

[26] S. Sudaryono, U. Rahardja, and H. E. Sari, "SISTEM PENDUKUNG KEPUTUSAN TERHADAP IMPLEMENTASI BELAJAR SISWA E-LEARNING UNTUK MENENTUKAN PENGEMBANGAN BELAJAR PADA SMK PUSTEK SERPONG,” J. Innov. Futur. Technol., vol. 1, no. 1, pp. 60-68, 2019. 